\title{
Identity, transcendence and the true self: Insights from psychology and contemplative spirituality
}

\begin{tabular}{|c|c|}
\hline $\begin{array}{l}\text { luthor: } \\
\text { Carter Haynes }\end{array}$ & 1,2 (1) \\
\hline $\begin{array}{l}\text { Affiliations: } \\
\text { Psychology D } \\
\text { William Jessu } \\
\text { Rocklin, Califo } \\
\text { States of Ame }\end{array}$ & $\begin{array}{l}\text { epartment, } \\
\text { p University, } \\
\text { rnia, United } \\
\text { rica }\end{array}$ \\
\hline $\begin{array}{l}\text { 2Department } \\
\text { Testament Stu } \\
\text { Theology, Uni } \\
\text { Pretoria, Sout }\end{array}$ & $\begin{array}{l}\text { of New } \\
\text { udies, Faculty of } \\
\text { versity of } \\
\text { h Africa }\end{array}$ \\
\hline $\begin{array}{l}\text { Project leader } \\
\text { Project numb }\end{array}$ & $\begin{array}{l}\text { : A.G. van Aarde } \\
\text { er: } 2334682\end{array}$ \\
\hline $\begin{array}{l}\text { Description: } \\
\text { Prof. Dr Carte } \\
\text { participating i } \\
\text { project, 'Biblic } \\
\text { and Hermene } \\
\text { Project “Holin } \\
\text { by Prof. Dr An } \\
\text { Aarde, profess } \\
\text { and senior res } \\
\text { the Faculty of } \\
\text { the University } \\
\text { South Africa. }\end{array}$ & $\begin{array}{l}r \text { Haynes is } \\
n \text { the research } \\
\text { cal Theology } \\
\text { utics - Ad Hoc } \\
\text { less"', directed } \\
\text { dries van } \\
\text { sor emeritus } \\
\text { search fellow in } \\
\text { Theology of } \\
\text { of Pretoria, }\end{array}$ \\
\hline $\begin{array}{l}\text { Correspondin } \\
\text { Carter Haynes } \\
\text { haynescarter1 } \\
\text { chaynes@jess }\end{array}$ & $\begin{array}{l}\text { g author: } \\
\text { s, } \\
\text { igmail.com; } \\
\text { sup.edu }\end{array}$ \\
\hline $\begin{array}{l}\text { Dates: } \\
\text { Received: } 30 \\
\text { Accepted: } 11 \\
\text { Published: } 17\end{array}$ & $\begin{array}{l}\text { Apr. } 2016 \\
\text { Aug. } 2016 \\
\text { Nov. } 2016\end{array}$ \\
\hline $\begin{array}{l}\text { How to cite th } \\
\text { Haynes, C., } 20 \\
\text { transcendenc } \\
\text { self: Insights f } \\
\text { and contempl } \\
\text { spirituality', H } \\
\text { Studies/Theol } \\
72(4), \text { a3455. } \\
\text { org/10.4102/l }\end{array}$ & $\begin{array}{l}\text { is article: } \\
16 \text {, 'Identity, } \\
\text { e and the true } \\
\text { rom psychology } \\
\text { ative } \\
\text { TS Teologiese } \\
\text { ogical Studies } \\
\text { http://dx.doi. } \\
\text { hts.v72i4.3455 }\end{array}$ \\
\hline $\begin{array}{l}\text { Copyright: } \\
\text { (c) 2016. The } \\
\text { Licensee: AOS } \\
\text { is licensed un } \\
\text { Creative Comr } \\
\text { Attribution Lic }\end{array}$ & $\begin{array}{l}\text { Authors. } \\
\text { is. This work } \\
\text { der the } \\
\text { mons } \\
\text { cense. }\end{array}$ \\
\hline Read online: & \\
\hline 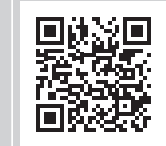 & $\begin{array}{l}\text { Scan this QR } \\
\text { code with your } \\
\text { smart phone or } \\
\text { mobile device } \\
\text { to read online. }\end{array}$ \\
\hline
\end{tabular}

This article investigates the intersection of psychology and spirituality as seen through the works of Thomas Merton, Carl Jung, Fritz Kunkel and Viktor Frankl. The themes of spirituality contextualised in human identity, psychological and spiritual transcendence, and the true self versus false self metaphor are traced through the works of all four thinkers. Epistemological flexibility and holistic thinking and being are suggested as methods for transforming interdisciplinary practitioners, such as pastoral counsellors, spiritual directors and spiritually oriented psychotherapists, in order that they can offer care in a less bifurcated and more integrated way. Practical applications, including a vignette and specific recommendations for broadening and deepening personal and professional integrative practice, are offered.

\section{Introduction}

Part of the appeal of dividing the self into 'true' and 'false' parts lies in developing a system of analysis that crosses the disciplinary line between psychology and spirituality, and that division attempts to aid therapists, spiritual directors, clergy and lay persons in the pursuit of personality development and spiritual formation. Because the boundary between psychology and spirituality is sometimes fiercely defended, the study of a concept spanning both sides of the science or faith dichotomy may help to facilitate mutual understanding between sometimes competing and often conflictual sides. Although the psychological construct of 'self' dates back to the advent of modern psychology, spiritual writers have been addressing similar content for millennia. For clinicians, directors and practitioners approaching this topic with a worldview already open to spiritual agency, the combination and interaction of psychological and spiritual knowledge is meant to assist in the creation of new understandings of and approaches to human development and healing.

As a point of departure, I take the blending of spirituality and psychology advanced by Thomas Merton, Carl Jung, Fritz Kunkel and Viktor Frankl. Merton takes contemplative spirituality as his starting point, while the others approach this topic from the perspective of psychology. My purpose is to energise and crystallise interdisciplinary thought by exploring the liminal space where the two disciplines have the most in common. Although my own background is mostly in psychology and human development, I have been engaged in a decades-long personal quest to make sense of the intersection between the psycho-emotional and spiritual or religious aspects of human experience. My views and the words I use to describe them have changed over the years, but my initial goal has not changed: to access the wisdom available through the integration of psychology and spirituality that is not available when one subject area is studied exclusively.

The choice of Merton as the sole representative from the spirituality side is based on his own reading and appreciation of Jung, his ability to translate his system into psychological terms, and that his spirituality is primarily contextualised within human identity. Also, Merton is famous for his writings on the true self versus false self dichotomy. On a more personal note, Merton has long been a favourite spiritual writer of mine and I have lived with him and his ideas over the course of 25 years. As such, his thoughts have penetrated my understanding of human nature, identity development and spiritual formation.

The psychological representatives (Jung, Kunkel and Frankl) form a historical thread from the beginnings of modern psychology to the mid-20th century, from analytic to existential theoretical orientations, and from non-theistic (Jung) to overtly theistic (Kunkel) worldviews. Taken together, they highlight a number of important trends that have arisen in psychology's interaction with religion and spirituality. Clearly, other or additional thinkers could have been chosen, but I thought it important to limit the number to three, and to choose psychological theorists whose 
writings evidence language ripe for comparison with Merton's musings on the concepts of self, identity and transcendence.

In the following, I dedicate a section each to an explanation of the basic tenets, main contributions and theoretical contributions of these four thinkers. These sections are followed by a final part in which I synthesise and build on some of the commonalities and synergies uncovered, introduce epistemological flexibility and a holistic approach, and suggest practical ways to put this newly contextualised knowledge into practice in pastoral care, spiritual direction, counselling and as a way of personally becoming more integrated human beings.

\section{Merton: The true self and contemplation}

Thomas Merton was a monk, author, spiritual practitioner and mystical theologian. He lived half his life within a religious order while maintaining broad intellectual, literary and religious interests. Merton was involved in interreligious dialogue and struggled with the tension between solitude and the call to an active life of engagement in social causes. In his many published books, letters and journals, the true self, transcendence of dualistic thinking, and a spirituality based on human identity all figure prominently. His very engaging and deeply authentic style of writing, along with his considerable personal experience as a monastic practitioner of contemplative prayer, has combined to make him one of the most sought-after spiritual writers of the 20th century.

In Merton's Palace of Nowhere, James Finley, a lifelong student of Merton's work, asserts that Merton's spirituality hinges on human identity (Finley 1999:17). He delves into Merton's juxtaposition of the true and false selves. Merton outlined a progressive transformation from an identity founded in the false (i.e. illusory, nonspiritual and worldly) self to a new identity founded in the true (i.e. spiritual, contemplative and enlightened) self. The false self is egocentric and concerned with meeting its own needs. The true self is other-focused and finds serenity through releasing the vestiges of egocentrism. The false self is one's most familiar identity, but is also superficial. It includes thoughts, emotions, personas, roles and social awareness. It is possible to reflect upon the false self, but even this introspection is superficial. Merton held that, in contemplation, one becomes aware of his or her true self and learns that the false self is limited. The false self erects barriers that must be surmounted before the true self can be explored and experienced (Merton 1972:7). Exploring one's own psychological defences is a way of labelling the false self more accurately.

Reilly and Thompson (2008:22-30) built on Finley's assertion that identity is basic to Merton's spiritual framework. Using the construct of 'personhood', they examined his work and found that unity, inclusiveness, integration and integrity comprise the essence of a mature identity. Unity refers to the wholeness or centredness that characterises an openness to people, religions, experience and knowledge. Inclusiveness captures the belief that serious practitioners of all religions share in a common reality. In his early work, Merton's integrative impulse was seen in his desire to reconcile opposing tensions, either in his own personality or externally in his relations with others. As he matured, integration came to include erasing distinctions between opposing poles and resolving presumed dichotomies by transcending his own dualistic thinking. He eventually came to see many of his original views as the result of false choices; his mature epistemology was clearly non-dualistic (Pramuk 2008:67). Integrity reflects correspondence between who one is and what one does, says and thinks. For Merton, it was not enough to believe and pray. He lived out his values through concrete actions, in his own personal and spiritual development and in his relationships.

For Merton, the true self is both a perfected version of our identity and a spiritual experience of ourselves and God. The process of coming to know our true self is spirituality expansive, but there is also the stark and unmediated clarity that contemplative awareness can bring. Contemplation does not allow the psychological comfort zones of the false self to survive. The false self is not capable of engaging in contemplative experience; the apprehension of the true self is one of the products of contemplation. Self-transcendence is the doorway from the false self to the true self (Merton 1972:1-13).

Merton's own words best convey his views. For example, in his book The Inner Experience, he devotes the first three chapters to discussing various aspects of the self:

One of the strange laws of the contemplative life is that in it you do not sit down and solve problems: you bear with them until they somehow solve themselves. Or until life itself solves them for you. Usually the solution consists in a discovery that they only existed insofar as they were inseparably connected with your own illusory exterior self. The solution of most such problems comes with the dissolution of this false self. And consequently another law of the contemplative life is that if you enter it with the set purpose of seeking contemplation, or worse still, happiness, you will find neither. For neither can be found unless it is first in some sense renounced. And again, this means renouncing the illusory self that seeks to be 'happy' and to find 'fulfilment' (whatever that may mean) in contemplation. For the contemplative and spiritual self, the dormant, mysterious and hidden self that is always effaced by the activity of our exterior self does not seek fulfilment. It is content to be, and in its being it is fulfilled, because its being is rooted in God. (Merton 2003:2)

Merton approaches the intersection between spirituality and psychology through the medium of the self, a concept used by both spiritual and psychological writers. Indeed, although it is defined slightly differently by each of the four thinkers considered in this article, the self in all its manifestations is more justifiably the domain of psychology. Why then does Merton spend so many of his words on this seemingly psychological concept? One answer is that he read and was 
affected by modern psychology, and a psychological way of understanding the human condition made its way into his personal understanding of spirituality. Merton's entire message about spiritual development is that maturity is not about what I believe, or even what I do or say. Mature spirituality must make its way into the very fabric of my being; it must be who I am. When who I am is changed by God, when my very identity - the way I see myself, the way I show up in relationships without having to think about it first - is transformed, I have become a new self, my true self.

\section{Jung: Individuation and spirituality}

Although Jung began his career under the tutelage of Freud and was even groomed as Freud's successor, significant theoretical differences between the two eventually led to a parting of company and a subsequent silencing of what had once been a fruitful dialogue. Jung later coined the term analytic psychology to differentiate his position from Freud's psychoanalytic school. For Jung, the concept of self was more central and salient than it was in the psychosexual model proposed by Freud. Also, rather than focusing on the identification and resolution of neuroses, Jung concentrated on explaining and enhancing selfhood. He defined self not in the modern sense of personal identity, but as a totality of personal experience and a balancing of competing conflicts and opposing spiritual and psychological forces (Maddi 1989:79-96). An accurate understanding of Jung's view of self must include the idea of individuation, by which he meant 'becoming a single, homogeneous being, and, in so far as "individuality" embraces our innermost, last, and incomparable uniqueness, it also implies becoming one's own self' (Jung 1959:143). Individuation is not about individualism, but about actualising the unique self that exists inside me. It is about reviewing and rejecting the possible versions of myself that are not in true keeping with my essence. Although Jung's road to individuation differs from Merton's path to the true self, the destination they both describe, and some of the steps along the way, sounds quite similar. For example, consider this excerpt from Merton's chapter on 'Things in Their Identity' from New Seeds of Contemplation:

For me to be a saint means to be myself. Therefore the problem of sanctity and salvation is in fact the problem of finding out who I am and of discovering my true self. Trees and animals have no problem. God makes them what they are without consulting them, and they are perfectly satisfied. With us it is different. God leaves us free to be whatever we like. We can be ourselves or not, as we please. We are at liberty to be real, or to be unreal. We may be true or false, the choice is ours. We may wear now one mask and now another, and never, if we so desire, appear with our own true face. (Merton 1972:31-32)

Merton's reference to wearing masks is almost certainly a nod towards Jung's persona archetype, which represents Jung's attempt to describe the social roles and facades people tend to take on (Jung 1959:137, 145). In popular culture, 'persona' has come to mean 'the person I choose to be or project in a particular situation'. Jung would add that our tendency to develop and use personas emanates from the collective unconscious and has been present since the dawn of human history.

The collective unconscious refers to Jung's view that, in addition to personal consciousness, we have a separate consciousness inherited from a universal store of all human experience throughout history. This and similar spiritualsounding terms have led many Jung enthusiasts to ascribe a mystical sensibility to his work. This attribution has been, in my view, quite inaccurate. Although Jung had had an apparent affinity for spirituality and religion, he also advocated making faith more palatable to the intellect: 'The concept of faith must therefore be purified, which is to say that faith must be relieved of its main difficulties, the mythical components which are particularly offensive to reason' (Jung 1971:44). He held that, even outside a religious context, people are religious by nature, and that devoting oneself to a higher cause or Being is an archetypal instinct fuelled by the collective unconscious (Jung 1971:45). Prior to the birth of scientific rationalism, belief in myth, religious or otherwise, was easier than in later times because it did not require any sacrifice of intellectual integrity. What was known about science and nature was not specific or authoritative enough to cast any doubt on Scriptural accounts such as the birth, life, death and resurrection of Jesus Christ or Moses' parting of the Red Sea. Rational life has increasingly created pressure to question unsubstantiated myths and opt instead for alternative 'religious' objects, such as reason and technology. For Jung, this shift was not so much about the unattractiveness of religious faith as it was evidence of the underlying need all humans have to believe in something. We are predisposed, by virtue of thousands of years of collective evolution, to seek relationships with higher entities or ideas. The Enlightenment simply revised the list of entities worthy of our 'worship'.

Jung often used the word 'numinous' to characterise spiritual or mythical phenomena, and one of his 'numinous' elements was 'the Sacred'. Although contained within the intra-psychic experience of the individual, the Sacred in Jung's typology parallels the same term in the field of theology. Jung tended to borrow terms from religious contexts and redefine them. For example, he believed that the religious function was an essential component of the psyche. He referred to religious material (as manifested through symbols, dreams and visions) as 'God images', and held that the central task of adult education was to communicate the archetypes and emanations of this God image (Stephens 2001:457).

Jung engaged in intellectual dialogue with a number of prominent theologians regarding the theological or psychological terms and concepts they had in common. These interchanges eventually proved frustrating to both parties: to Jung because the theologians were not willing to abandon extra-human agency, and to the theologians as they came to realise that Jung was not willing to venture outside the confines of the human psyche in search of truth. 
The series of disputations between Jung and Martin Buber is particularly instructive.

In 1952, Buber published the article 'Religion and Modern Thinking' (Buber 1988). In it, he criticised Jung on the grounds that his views represented a subjectivism so radical that it blocked apprehension of the transcendent and led to spiritual short-sightedness. Buber saw Jung's talk as pseudo-religious because it did not relate to a Deity. Buber charged that Jung had overstepped the intellectual boundaries of psychology without taking responsibility for the religious statements he made (Stephens 2001:464). This lack of ownership allowed Jung to occupy the space between the disciplines of psychology and theology without having to be completely accountable to the formal rules of either one. ${ }^{1}$

One of Buber's main theological premises was that an 'I-Thou' relationship exists between individuals and the Divine. In response to Jung's insistence that God exists only intra-psychically, Buber retorted that religion cannot be at the same time contained within consciousness (collective or otherwise) and also a relation of an ' $\mathrm{I}$ ' to a 'Thou', as this would imply that the I and the Thou are one and the same entity (Stephens 2001:464).

In brief, although Jung evidenced signs of openness to mystical and religious experience and extra-human spiritual agency, he was unable to break through the bounds of his empirical worldview. Jung was not willing to concede a spiritual reality that exists outside of and separate from the workings of the human mind and its collective connections with historical human consciousness. Although he had opened a door to discussion and debate on the psychology of spiritual experience (that many others have walked through), he personally never moved beyond a rationalist understanding of human spirituality.

\section{Kunkel: Human and spiritual relatedness}

Fritz Kunkel was a physician and psychoanalyst who, as a result of conversations and correspondence with Jung, adopted the latter's view of individuation. From Freud, who was also his psychoanalyst, Kunkel gleaned an appreciation of the relationship between childhood experience and adult personality formation, but Kunkel's unique synthesis focused on the nature and origins of egocentricity. He is also notable for the way he seamlessly combined clinical, scientific and religious worldviews in his thinking and writing (Sanford 1984:paras. 6-8).

Kunkel called his approach 'We-Psychology' to emphasise the importance of relatedness with both other people and the Divine (Barrow 1988:paras. 1-3). The 'original We' is the

1.Occupying the space 'between' psychology and theology (i.e., engaging both without atempting to follow the rules of ether) is not what (i.eng advocating when without ate inpterdisciplinary and active engagem is not wh integration. In gem encourage interdisciplinary and active engagement with integration. In geometric terms, what l am suggesting could be called 'intersection', while what Buber accuse Jung of could be called the 'disjointed' approach (from 'disjoint', where the intersection of two sets is the null set). formative relationship between child and parent, and the security of a healthy parent-child bond is indicative and symbolic of the ideal relation between people and their God. Egocentricity disrupts both child-caregiver and humandivine relationships. As people encounter 'maturing $\mathrm{We}^{\prime}$ experiences (i.e. life crises), their relationships can become more objective and whole. Kunkel saw 'We-ness' as the main force of healing and reconciliation for humanity (Steere 1985:150):

Very often, the We-experience includes actions and reactions which remain unconscious for a certain time or even forever. Suppose you try to comfort a person who has lost his father by death. You will be aware of your compassion in general. You will be touched or even deeply moved, and all your words and gestures will be, as it were, imbibed by your We-feeling. You will be conscious of the fact that you are motivated not by private emotion, but by a common reaction to a common loss. Yet the We-experience may reach much deeper. You may not until much later understand that the person you comforted has become your brother, and that you are connected with him to a new unit, since you have looked together into the depths of human life. That is We-experience. (Kunkel 1984:68)

For Kunkel, all relational phenomena have their genesis in the original Ground of Relatedness. The ability to desire, pursue, engage in and appreciate relatedness involves both the juxtaposition of one ego to another, and the understanding that the 'small we' is part of the 'big We'. Spirituality without the aid and expertise of psychology is ill prepared to solve the deeper mental and emotional problems people face. Conversely:

Psychology cannot rescue us without the help of religion. It is doomed to deteriorate into mere psychologism, just as theology without psychology deteriorates into theologism. The depth is lost and only platitudes remain. (Kunkel 1943:26)

Kunkel believed that people are most actualised when they are aware of their own creativity and are moving towards We-ness, but that they are also free to ignore the human condition, the existence of God and their own creative power. The consequences of this avoidance are suffering and pain; therefore, people must be creative, even at the risk of failure. Faith is needed to bridge the gap between our freedom to act creatively and the inevitability of making mistakes. Kunkel espoused the Jungian view that opposing forces - life and death, masculine and feminine, tension and relaxation create polarities in the human experience, and he held out religious self-education as the path that brings balance. Rather than rejecting or demonising the 'negative' side of a dichotomy, individuals must be open to finding the most helpful blending of two extremes (Kunkel 1943:11-35). Dealing with dichotomies by transcending binary thinking is also a theme in Merton's writing, and has been covered in detail more recently by Richard Rohr (2014).

Religious self-education, at first blush, may connote attending religious classes or enrolling in seminary, but the intent here is much broader. Kunkel is referring to a holistic process of self-development which simultaneously touches 
on psychological, spiritual and emotional components of experience. One technique that can serve as an example of religious self-education is 'confessional meditation'. This practice involves the movement of psychic material from the unconscious to conscious awareness, which is best facilitated in an atmosphere of openness and prayer. Confessional meditation can be partially understood by contrasting it with conventional confession, that between a penitent and a confessor. In that context, the act can be made overly formal (at least in the mind of the parishioner) merely by the presence of the confessor. Although a traditional confession is likely to stir up unconscious material, it is not designed to examine the nature of unconscious urges and conflicts, even when the confessor has the training to interpret such things. There is also a disinclination for the supplicant to assume personal responsibility for the unconscious material spurring the problematic actions, particularly when assigned penance can be interpreted as negating any personal characteristics that led to the indiscretion (Kunkel 1943:251).

Confessional meditation makes use of one's personal meditative practice. In unitive experience, the normal boundary between unconscious and conscious material becomes diffuse. The practitioner is thereby enabled to collect previously unconscious motivations and carry them forward into conscious awareness. The physical and mental relaxation associated with the meditative state allows for psychological integration of previously unconscious elements (Camacho 1991:189-187; Kunkel 1943:262-288). Clearly, this solitary ritual will not work for everyone. It requires both an established contemplative practice and a certain amount of psychological sophistication; but for those who possess both, speaking also from personal experience, confessional meditation can be a potent way to make substantial progress on a number of fronts (e.g. spiritual, psychological and relational) in a relatively short period of time.

Kunkel developed 'We-psychology' as an antidote to the stifling emotional and intellectual entropy that often attends prolonged egocentricity. In so doing, he suggested that relatedness is preferable to aloneness. In Merton's terms, the egocentricity that was the focus of Kunkel's model is associated with the false self. Kunkel saw the discovery of the true self as the goal of attempts to transform egocentricity. People have the tendency to present facades, based on particular social situations, so as to increase the likelihood that they will be accepted or validated by others. These outwardly expressed and changing presentations (Jung's personas) are manifestations of the false self. The path towards emotional and spiritual maturity involves the progressive rejection of the shallow self-projections presented for the consumption of others, and the identification and development of the central, integrated identity, the true self. This self, for Kunkel, is not a psychological self, but a holistic self that includes all aspects of identity and spirituality. More will be discussed about the importance and role of holism as a theoretical position in the final section below.
While Jung rejected non-human spiritual agency in the development of the human psyche, Kunkel integrated psychodynamic psychology with a theistic spirituality and techniques aimed at achieving his stated goal of transforming lives. The presence of contemplative, mystical forms of meditative practice as the bridge between conscious and unconscious processes places spirituality at the core of psychological maturity. Although Kunkel is not as well known as Jung or Frankl, his ideas seem particularly well suited to the current task of exploring the intersection between psychology and spirituality, especially as that liminality concerns itself with Merton's concepts of identity, transcending binary thinking and establishing the true self as the archetypal best version of the individual.

\section{Frankl: Existence, transcendence and meaning}

Viktor Frankl knew Freud and was influenced by him during the early part of his career, but he was more closely allied with existential psychology (e.g. see Binswanger 1963; Boss 1963; May 1958). Frankl's work is known as the third Viennese school in that it followed after Freud's and Adler's works. He was trained as both a psychiatrist and a neurologist, and was one of only two members of his family to survive the Nazi death camps. Frankl's most famous book, Man's Search for Meaning, portrays the 'courageous confrontation and the transformation of suffering that is a hallmark of existential psychology' (Greening 1998:10-11). It was written in only nine days shortly after he resumed work following his liberation from the Nazis (Langle \& Sykes 2006:41). The book has been rated as one of the ten most influential books read by respondents in a survey conducted by the United States Library of Congress. The following excerpt hints at the deep experiential context of Frankl's writing and life. It recounts his memory of arriving at the first Nazi camp by train:

With the progressive dawn, the outlines of an immense camp became visible: long stretches of several rows of barbed wire fences: watch towers; searchlights; and long columns of ragged human figures, grey in the greyness of dawn, trekking along the straight desolate roads, to what destination we did not know. There were isolated shouts and whistles of command. We did not know their meaning. My imagination led me to see gallows with people dangling on them. I was horrified, but this was just as well, because step by step we had to become accustomed to a terrible and immense horror. Eventually we moved into the station. The initial silence was interrupted by shouted commands. We were to hear those rough, shrill tones from then on, over and over again in all the camps. Their sound was almost like the last cry of a victim, and yet there was a difference. It had a rasping hoarseness, as if it came from the throat of a man who had to keep shouting like that, a man who was being murdered again and again. (Frankl 2006:9-10)

In all, Frankl published 32 books and his writings have been translated into 25 languages (Greening 1998:10-11). Logotherapy was the practical application of his psychological theory; he meant logos to imply 'the spiritual' or 'the meaning' (Frankl 1955:17). Before true change or healing can come 
about, people must confront the loss of meaning that is synonymous with modern human existence. He refers to this meaninglessness as an 'existential vacuum', and the remedy has to do with 'showing the creative potentiality of a free and responsible human spirit to achieve meaning in the face of tragedy and despair' (Johnson 1970:92). Frankl contrasted logotherapy with what he saw as the manipulative and relationally empty techniques of Freudian and Adlerian psychotherapy; he believed that every theory of personality or psychotherapy is based on an explicit or implicit ontology:

Logotherapy, in comparison with psychoanalysis, is a method less retrospective and less introspective. Logotherapy focuses rather on the future, that is to say, on the meanings to be fulfilled by the patient in his future. (Logo-therapy, indeed, is a meaningcentered psychotherapy.) At the same time, logotherapy defocuses all the vicious-circle formations and feedback mechanisms which play such a great role in the development of neuroses. Thus, the typical self-centeredness of the neurotic is broken up instead of being continually fostered and reinforced. (Frankl 2006:98)

Frankl approached logotherapeutic interactions as personal and existential encounters. By contrast, he characterised the reductionism of psychoanalysis and the objectification of radical behaviourism as espousing what he called the 'nothing but' view of humanity. To say or imply that humans are 'nothing but' collections of libidinal urges or that people are motivated only by the pursuit of pleasure and the avoidance of pain is to deny their freedom of choice. We are just as free to overcome environmental and existential barriers as we are to be controlled by them (Lowen 2000:55).

Frankl's theory also evidences a sociological sensibility in the tradition of Durkheim (1976), Weber $(1963,2005)$ and Marx (Marx \& Engels 1964). 'Expressions of meaninglessness and despair were not only individual experiences recounted in therapy and counselling sessions, they also reflected the consequences of greater social, economic, technological, and political events' (Langle \& Sykes 2006:44). Addressing the existential vacuum in the lives of his patients was intimately related to confronting the larger sociopolitical conditions of life. This paradigm is in contrast to Jung's intensely intra-personal approach to self-development. Kunkel, although his approach is more holistic than Jung's approach, was still focused squarely on the mind, spirit and emotions of the individual. By taking a more collective view of human suffering and healing, Frankl moves away from an exclusively psychological stance towards a more inclusive and flexible epistemology. As will be seen in the final section, epistemological flexibility is a prerequisite for engaging in truly integrative and interdisciplinary work, both in one's personal development and in offering help to others through pastoral care, spiritual direction or counselling.

Frankl speaks of a 'will-to-meaning': 'that which most deeply inspires and pervades man; ... the innate, albeit often unconscious and sometimes even repressed, desire to give as much meaning as possible to one's life, to realise as many values as possible' (Frankl 1955:17). This construct addresses the volitional and ontological substrate of human nature; the currency of this meaning is spirituality. Logotherapy is directed at the spirit and at the spiritual work of regeneration (Frankl 1956:20). Frankl was Jewish, but did not attach any particular religious understanding to his public views on spirituality. He saw meaning as a spiritual need, and left the door open for practitioners and clients to apply their own religious overlay to the existential raw material he uncovered. As most of Frankl's medical colleagues did not share his penchant for integrating philosophy and spirituality into clinical practice, he frequently included arguments in his books and articles that were aimed at justifying his holistic view of human nature and healing cures. The following is an example:

It is philosophical dilettantism to rule out ... the existence of a divine being on the ground that the idea of God arose out of primitive man's fear of powerful natural forces. It is equally false to judge the worth of a work of art by the fact that the artist created it in, say, a psychotic phase of his life ... It is throwing out the baby with the bathwater to repudiate the inner validity and the unique value of an artistic creation or religious experience simply because these may be used by an individual for his own neurotic purposes, or by a culture for its own decadent ends. (Frankl 1956:59-60)

Without meaning, humanity is ontologically bankrupt and suffering is pointless. Spirituality implies transcendence and people can only become their true selves by transcending their humanity. 'Transcendence is the essence of existence' (Frankl 1962:100). Whether applied to borrowed and wornout personas (Jung), blocks in psychological awareness (Kunkel), or being caught in a cycle of meaningless existence (Frankl), transcendence is a thread that can be followed through all four of the thinkers considered here. As we have seen, Merton uses the idea of transcendence as his method of choice for eschewing the many spiritual and theological problems that come about as a result of binary thinking.

For Frankl, freedom comes when we partake of some context, some way of knowing, that is separate from our self-same, insular identity. The true self, by the extension of Frankl's views into the language that metaphor, can be defined as the portion of personal psychological structure that remains when sufficient confrontation with the existential vacuum has cleared away the chaff of the false self. Existential psychology tends to take a harsh and realitybased approach to human development. Frankl's system is no exception. His route towards the true self travels through pain, suffering and angst. By definition, false personas cannot withstand the demands of truth. The heroic task of advancing through life with one's eyes open and without discarding the freedom to choose produces a meaning-rich and sanctified life imbued by the true self.

\section{Epistemological flexibility, holism and practical applications}

If identity, transcendence and the true self are themes that run through the foregoing, what can be learnt from 
considering them? What new trail can be cleared through the very old forest of thinking about integration? I would like to suggest that it is the combination of psychological and spiritual considerations that is particularly compelling. Each of us approaches the imaginary line between the two disciplines with our own set of presuppositions and prejudices. Although this cannot be avoided, an awareness of personal, epistemological blind spots is indispensable. In a similar way to how individuals grow based on new psychospiritual insight and awareness, scholars, psychologists, theologians and clergy are able to metabolise more inclusive integrative thinking as they expose themselves to alternatives not previously considered. The relationship between researchers, their chosen methodology, their subjects and the new knowledge they create has been investigated in this context (Haynes 2010:36). In particular, when there is a pre-existing epistemological divide between researchers and subjects (as when Western scholars conduct research on non-Western participants), flexibility in both thought and method allows for learning to take place amongst the teachers. This learning, and the adjustments and allowances that result from it, makes both the design and the results of the study more responsive to the participants as they actually exist in the world, rather than to the researcher's predetermined, culturebound and possibly fear-based presuppositions about the 'problem' under consideration.

The same critique can be applied to the study of the intersection of psychology and spirituality. Interdisciplinarity requires openness, awareness and flexibility not only because of turf disputes between academic fields but also because of personal values and beliefs about our own and 'the other' disciplines. Many psychologists believe that spirituality exists only in the mind or brain. Many religious individuals question the philosophical foundations of psychological theories. I have found that inclusive and synergistic thinking across the psychology or spirituality line is particularly fraught with hidden snares not evident elsewhere (as with interdisciplinary studies within the social sciences). The gap here is wider and harder to traverse. This being the case, those who wish to explore this rich area are well advised to engage in a moment of self-reflection before proceeding.

One of the definitions of 'holism' is that the whole is somehow greater than the sum of its parts. Holistic thought, the opposite of the reductionism characteristic of the scientific method, is applied in many areas, including human development. 'Applying this theorem epistemologically, we could say that a holistic view is greater than the sum of the specialised views that contribute to it' (Haynes 2009:53). There is something about looking at both psychological and spiritual ways of interpreting and understanding human experience that enriches the process beyond what could have been gleaned from either perspective used exclusively.

\section{Practical application: A vignette}

As an illustration of this point, consider Karen (name altered), a 33-year-old woman, mother of two young children, housewife, and churchgoer. Over the course of approximately one year, she begins to feel very disillusioned with her life. She loves her family, and she enjoys her friends at church, but she just feels like something is missing. She does not know what it is, but she feels compelled to find it; therefore, she decides to make an appointment with her pastor to talk about her despondency, foreshortened sense of the future and general unhappiness. She also feels embarrassed that she feels this way. Her pastor, a well-meaning man with Bible training but without any formal education or training in counselling, suggests that she should increase her personal prayer, spend more time reading the scriptures and be more involved in church activities. She tries this for about six months, and feels closer to God as a result. Her social connections also improve as she becomes more involved with other ladies at her church, but her gnawing feeling that something is missing from her life is only intensified by her re-dedication to religious and spiritual practice.

She learns about a spiritual director at another local church and decides to try spiritual direction. Her director encourages her to investigate how God might be showing up in her life in unexpected ways, or how God might be calling her to some new realisation or practice. The director introduces her to a few spiritual techniques Karen had not previously been aware of, and suggests a book about contemplative meditation. She finds this extremely helpful, and integrates some contemplative practices into her personal devotions. She prays to know what God might be leading her towards in this journey of dryness and disillusionment, and comes to realise that she is travelling through a 'dark night'. This helps her to see her current plight of spiritual aridity as something God is allowing her to go through for the purpose of making her stronger, and she takes joy in the knowledge that, eventually, she will again experience God's consolation.

Several months later, still in the dark night, she begins experiencing intrusive and obsessive thoughts about drowning her youngest child. It comes up especially when she bathes the child, but at other times as well. She is very embarrassed about this and thinks she might be 'going crazy'. In no way can she interpret these thoughts as having anything to do with spiritual purgation, and she is afraid even to tell her director about them. Her anxiety about these thoughts affects her sleep, and her insomnia makes the thoughts and her general mood worse. On the advice of her best friend and her husband, she seeks professional counselling. The counsellor, after about 30 minutes of questioning, diagnoses her with acute anxiety and recommends a medication evaluation. This evaluation results in a prescription for an anti-anxiety agent, which she takes and which causes substantial relief, both of the intrusive thoughts about her youngest child and of her negative outlook on the future. Subsequent counselling sessions reveal a tendency towards perfectionism in Karen, and resulting anxiety and low self-esteem when she fails to meet unattainable standards. This state of affairs was the result of growing up with an alcoholic father who was 
unpredictable and sometimes violent. The only way Karen knew to avoid her father's displeasure was to be 'perfect' and that became her coping strategy. Her inability to be perfect produced anxiety which, unacknowledged and untreated for many years, eventually escaped her control in the form of unacceptable and intrusive thoughts.

This extended vignette is offered as an attempt to show the complicated web that can be created between one person's life experience and the various practitioners she seeks out. None of these practitioners did anything 'wrong' based on their own professional standards, but the care Karen received was quite different in each setting. Her pastor offered a religious cure, her director a spiritual one, her counsellor a psychological one, and her physician a biological one. Which was the best? Which did she really need? All of them.

Now envision a practitioner who had successfully crossed the line between spiritual or religious and psycho-emotional explanations, conceptualisations and applications. Because she (the practitioner) has previously confronted her own epistemological and ontological issues, interdisciplinary thinking has become a natural part of her approach to others, that is, a part of her identity, of her true self. Because of her holistic view of human and spiritual needs and development, she is able to contextualise the spiritual, religious, psychological and physical facets of Karen's presentation. She can support and encourage Karen's church involvement and religious identity; she can emphasise the acceptability of questioning and challenging the spiritual status quo in search of deeper meaning and more accurate self-assessment; she can assess Karen's tendency towards dealing with both internal and external stress by developing symptoms of anxiety; and she can embolden Karen to care for her physical body, including taking required medication.

Clearly, the transcendence of dualistic thinking, a redefinition of identity and an exploration of the true self are evident in this vignette, both in the practitioner and in Karen. Without having previously transcended the dichotomy between spirituality and psychology, the practitioner cannot approach Karen with a healing perspective that is integrated. Without her own personal practice aimed at uncovering her true self and distinguishing it from the false, she cannot model this process to Karen. Whether she focuses on Karen's budding contemplative spiritual practice (Merton), her lack of individuation (Jung), her impaired relatedness and egocentricity (Kunkel) or her existential struggle with the big questions of life (Frankl), she cannot impart a solution that she has not personally experienced herself.

\section{Implications}

Depending on one's particular field and training, the practical steps to be taken in implementing the recommendations above will look quite different. Spiritually oriented psychotherapists, especially when working with clients open to contemplative practice, can use the true self metaphor as a readily understandable and explainable framework, regardless of their underlying theoretical orientation. Client homework assignments could include reading and reflection on spiritual texts dealing with the true and false selves. This sort of bibliotherapy has the advantage of translating complex psychological processes into nontechnical, accessible and inspiring language. Spiritual directors and pastoral counsellors can add psychological writings focused on the self, identity development and transcendence to their own preparation as a way of deepening their ability to facilitate spiritual transformation. Although directors and clergy trained in counselling receive some exposure to psychological theories and techniques as part of their study, becoming immersed in Kunkel or Frankl for a time would likely refresh and enliven their epistemological flexibility and holistic worldview.

One reason individuals tend not to grow emotionally or spiritually after adolescence is that the necessities of life crowd out attempts at self-improvement. Contextualising spirituality within human identity and using metaphors like transcendence and the true self can make continued development more accessible to busy and under-resourced people. Because these themes are based on a wealth of spiritual and psychological thought and practice, they have the substance to sustain and rejuvenate depth and meaning. Because of their epistemological flexibility and holistic focus, these concepts can be applied in non-Western contexts. Future work in this area might focus the themes of this study on a particular cultural, social, psychological or religious issue.

\section{Acknowledgements Competing interests}

The author declares that he has no financial or personal relationships which may have inappropriately influenced him in writing this article.

\section{References}

Barrow, H., 1988, 'Book review: Creation continues', Monastic Interreligious Dialogue 32 (May).

Binswanger, L., 1963, Being-in-the-world: Selected papers of Ludwig Binswanger, Basic Books, New York.

Boss, M., 1963, Psychoanalysis and daseinanalysis, Basic Books, New York.

Buber, M., 1988, 'Religion and modern thinking', in M. Buber (ed.), Eclipse of God: Studies in the relation between religion and philosophy, Ch. 5, pp. 53-81, Humanities Press International, Atlantic Highlands, NJ.

Camacho, H.S., 1991, 'A synthesis of Moltmann's archetypal Christology with Jung's God-image archetype: A theological psychology for pastoral counseling and psychotherapy', PhD thesis, School of Theology at Claremont, Claremont, CA, viewed 11 June 2015, from http://search.proquest.com/docview/303969723

Durkheim, E., 1976, The elementary forms of the religious life, The Free Press, New York.

Finley, J., 1999, Merton's palace of nowhere, Ave Maria Press, Notre Dame, IN.

Frankl, V., 1955, 'Concept of man in psychotherapy', Pastoral Psychology 6 (Nov), 16-26. http://dx.doi.org/10.1007/BF01791329

Frankl, V., 1956, 'From psychotherapy to logotherapy', Pastoral Psychology 7, 56-60. http://dx.doi.org/10.1007/BF01564772

Frankl, V., 1962, 'Psychiatry and man's quest for meaning', Journal of Religion and Health 1, 93-103. http://dx.doi.org/10.1007/BF01532076

Frankl, V., 2006, Man's search for meaning, Beacon Press, Boston, MA.

Greening, T., 1998, 'Viktor Frankl, 1905-1997', Journal of Humanistic Psychology 38(1), 10-11. http://dx.doi.org/10.1177/00221678980381002 
Haynes, C., 2009, 'Holistic human development', Journal of Adult Development 16(1) 53-60, viewed 11 June 2015, from http://link.springer.com/article/10.1007/ s10804-009-9052-4

Haynes, C., 2010, 'A case for flexible epistemology and metamethodology in religious fundamentalism research', Integral Review 6(3), 36-56, viewed 11 June 2015 , from http://integral-review.org/documents/Haynes, $\% 2$ Religious $\% 20$ Fundamentalism\%20Research,\%20Vol.\%206,\%20No.\%203.pdf

Johnson, P.E., 1970, 'The will to meaning: Foundations and applications of logotherapy', Journal of Religion and Health 9, 91-93.

Jung, C., 1959, 'The relations between the ego and the unconscious', in V. Staub De Laszlo (ed.), The basic writings of C. G. Jung, pp. 105-182, Random House, New York.

Jung, C., 1971, 'Religionless Christianity', Journal of the American Academy of Religion 39(1), 43-47. http://dx.doi.org/10.1093/jaarel/XXXIX.1.43

Kunkel, F., 1943, In search of maturity, Charles Scribner's Sons, New York.

Kunkel, F., 1984, 'The "we experience", in J. Sanford (ed.), Fritz Kunkel: Selected writings, pp. 66-73, Paulist Press, New York.

Langle, A. \& Sykes, B.M., 2006, 'Viktor Frankl - Advocate for humanity: On his 100th birthday', Journal of Humanistic Psychology 46(1), 36. http://dx.doi.org/10.1177/ 0022167805281150

Lowen, J., 2000, 'Viktor Frankl, the champion of humanness', Free Inquiry 21(1), 55

Maddi, S., 1989, Personality theories: A comparative approach, 5th edn., Dorsey, Homewood, IL.
Marx, K. \& Engels, F., 1964, On religion, Schocken Books, New York.

May, R., 1958, 'Contributions of existential psychotherapy', in R. May \& E. Angel (eds.), Existence: A new dimension in psychiatry and psychology, Basic Books, New York.

Merton, T., 1972, New seeds of contemplation, New Directions, New York.

Merton, T., 2003, The inner experience: Notes on contemplation, HarperSanFrancisco, San Francisco, CA.

Pramuk, C., 2008, "'Something breaks through a little": The marriage of Zen and Sophia in the life of Thomas Merton', Buddhist - Christian Studies 28, 67, viewed 11 June 2015, from http://www.jstor.org/stable/30152928?seq=1\#page_scan_ tab_contents

Reilly, R. \& Thompson, P.M., 2008, 'Thomas Merton on the contemplative life and personhood', Cithara 48(1), 22-30.

Rohr, R., 2014, 'Dualistic Thinking' in Richard Rohr's Daily Meditation, viewed 26 Apri 2016, from http://conta.cc/1e50I6U

Sanford, J., 1984, 'Fritz Kunkel: Alive today', Inward Light XLVI(100), Views and Reviews, 1-3.

Steere, D., 1985, 'Fritz Kunkel: Selected writings', Theology Today 42(1), 150.

Stephens, B.D., 2001, 'The Martin Buber-Carl Jung disputations: Protecting the sacred in the battle for the boundaries of analytical psychology', Journal of Analytical Psychology 46, 455-491. http://dx.doi.org/10.1111/1465-5922.00257

Weber, M., 1963, The sociology of religion, Beacon Press, Boston, MA.

Weber, M., 2005, The Protestant ethic and the spirit of capitalism, Routledge, London. 